\title{
Front Matter: Volume 10853
}

, "Front Matter: Volume 10853," Proc. SPIE 10853, Optical Imaging, Therapeutics, and Advanced Technology in Head and Neck Surgery and Otolaryngology 2019, 1085301 (17 May 2019); doi: 10.1117/12.2531185

SPIE. Event: SPIE BiOS, 2019, San Francisco, California, United States 


\section{PROGRESS IN BIOMEDICAL OPTICS AND IMAGING}

\section{Optical Imaging, Therapeutics, and Advanced Technology in Head and Neck Surgery and Otolaryngology 2019}

Brian J. F. Wong

Justus F. llgner

Editors

2 February 2019

San Francisco, California, United States

Sponsored and Published by

SPIE 
The papers in this volume were part of the technical conference cited on the cover and title page. Papers were selected and subject to review by the editors and conference program committee. Some conference presentations may not be available for publication. Additional papers and presentation recordings may be available online in the SPIE Digital Library at SPIEDigitalLibrary.org.

The papers reflect the work and thoughts of the authors and are published herein as submitted. The publisher is not responsible for the validity of the information or for any outcomes resulting from reliance thereon.

Please use the following format to cite material from these proceedings:

Author(s), "Title of Paper," in Optical Imaging, Therapeutics, and Advanced Technology in Head and Neck Surgery and Otolaryngology 2019, edited by Brian J. F. Wong, Justus F. llgner, Proceedings of SPIE Vol. 10853 (SPIE, Bellingham, WA, 2019) Seven-digit Article CID Number.

ISSN: 1605-7422

ISSN: 2410-9045 (electronic)

ISBN: 9781510623484

ISBN: 9781510623491 (electronic)

Published by

SPIE

P.O. Box 10, Bellingham, Washington 98227-0010 USA

Telephone +1 3606763290 (Pacific Time) · Fax +1 3606471445

SPIE.org

Copyright (C) 2019, Society of Photo-Optical Instrumentation Engineers.

Copying of material in this book for internal or personal use, or for the internal or personal use of specific clients, beyond the fair use provisions granted by the U.S. Copyright Law is authorized by SPIE subject to payment of copying fees. The Transactional Reporting Service base fee for this volume is $\$ 18.00$ per article (or portion thereof), which should be paid directly to the Copyright Clearance Center (CCC), 222 Rosewood Drive, Danvers, MA 01923. Payment may also be made electronically through CCC Online at copyright.com. Other copying for republication, resale, advertising or promotion, or any form of systematic or multiple reproduction of any material in this book is prohibited except with permission in writing from the publisher. The CCC fee code is $1605-$ $7422 / 19 / \$ 18.00$.

Printed in the United States of America by Curran Associates, Inc. under license from SPIE.

Publication of record for individual papers is online in the SPIE Digital Library.

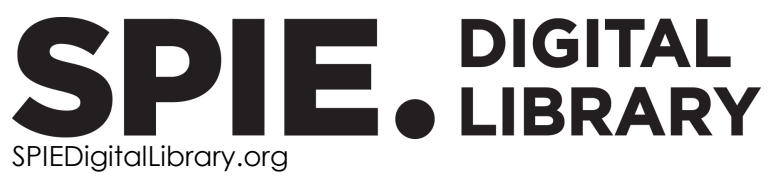

Paper Numbering: Proceedings of SPIE follow an e-First publication model. A unique citation identifier (CID) number is assigned to each article at the time of publication. Utilization of CIDs allows articles to be fully citable as soon as they are published online, and connects the same identifier to all online and print versions of the publication. SPIE uses a seven-digit CID article numbering system structured as follows:

- The first five digits correspond to the SPIE volume number.

- The last two digits indicate publication order within the volume using a Base 36 numbering system employing both numerals and letters. These two-number sets start with $00,01,02,03,04$, 05, 06, 07, 08, 09, 0A, OB ... 0Z, followed by 10-1Z, 20-2Z, etc. The CID Number appears on each page of the manuscript. 


\title{
Contents
}

\author{
$\checkmark \quad$ Authors \\ vii Conference Committee
}

OPTICAL TECHNOLOGIES FOR ASSESSMENT AND GUIDANCE OF MIDDLE AND INNER EAR STRUCTURES AND BEYOND

$1085307 \quad$ Inner ear cellular imaging through scattering bone [10853-6]

OCT AND RELATED SYSTEMS FOR MONITORING, MODIFYING AND FUNCTIONAL ASSESSMENT OF UPPER AIRWAYS II

10853 OG The new method for treatment of larynx stenosis based on transplantation of rib cartilage reshaped with 1.56- $\mu \mathrm{m}$ laser radiation [10853-13]

$10853 \mathrm{OH} \quad$ Concept for high speed vocal cord imaging with swept-source optical coherence tomography [10853-14]

CONCEPTS IN OPTICAL IMAGING FOR EARLY DETECTION OF HEAD AND NECK MALIGNANCIES

10853 OK In vivo Raman spectroscopy: monitoring cancer progression post carcinogen withdrawal [10853-17]

$10853 \mathrm{OL} \quad$ Fluorescence of carbazole derivatives for screening of human cancer [10853-18]

OPTICAL AND RELATED IMAGING FOR DETECTION AND ASSESSMENT OF INVASIVE HEAD AND NECK CANCER

10853 OP Paired-agent imaging for detection of head and neck cancers [10853-21] 
Proc. of SPIE Vol. 10853 1085301-4

Downloaded From: https://www.spiedigitallibrary.org/conference-proceedings-of-spie on 26 Apr 2023 Terms of Use: https://www.spiedigitallibrary.org/terms-of-use 


\title{
Authors
}

Numbers in the index correspond to the last two digits of the seven-digit citation identifier (CID) article numbering system used in Proceedings of SPIE. The first five digits reflect the volume number. Base 36 numbering is employed for the last two digits and indicates the order of articles within the volume. Numbers start with 00, 01, 02, 03, 04, 05, 06, 07, 08, 09, OA, OB...0Z, followed by 10-12, 20-2Z, etc.

\author{
Alexandrovskaya, Yu. M., OG \\ Baum, O. I., OG \\ Benecke, Hannes, $\mathrm{OH}$ \\ Chang, Cheng-Chung, OL \\ Chang, Ta-Chau, OL \\ Chen, Eunice Y., OP \\ Chen, Wei-Wen, OL \\ Chu, I-Te, OL \\ Heisterkamp, Alexander, $\mathrm{OH}$ \\ Ingle, Arvind, OK \\ Kumar, Piyush, OK \\ Lin, Mei-Chun, OL \\ Lou, Pei-Jen, OL \\ Marra, Kayla, OP \\ Meyer, Heiko, $\mathrm{OH}$ \\ Müller-Wirts, Lennart, $\mathrm{OH}$ \\ Murali Krishna, C., OK \\ Park, Yeonjae, OP \\ Psaltis, Demetri, 07 \\ Ripken, Tammo, $\mathrm{OH}$ \\ Romito, Marilisa, 07 \\ Samkoe, Kimberley S., OP \\ Sharifpourboushehri, Sara, $\mathrm{OH}$ \\ Sobol, E. N., OG \\ Stankovic, Konstantina M., 07 \\ Starostina, S. V., OG \\ Svistuskin, V. M., OG \\ Tichaver, Kenneth M., OP \\ Tseng, Ting-Yuan, OL \\ Wang, Chiung-Lin, OL \\ Zabic, Miroslav, $\mathrm{OH}$
}


Proc. of SPIE Vol. 10853 1085301-6

Downloaded From: https://www.spiedigitallibrary.org/conference-proceedings-of-spie on 26 Apr 2023 Terms of Use: https://www.spiedigitallibrary.org/terms-of-use 


\section{Conference Committee}

Symposium Chairs

James G. Fujimoto, Massachusetts Institute of Technology (United States)

R. Rox Anderson, Wellman Center for Photomedicine, Massachusetts General Hospital (United States) and Harvard Medical School (United States)

Symposium Chairs

Jennifer K. Barton, The University of Arizona (United States)

Wolfgang Drexler, Medical University of Vienna (Austria)

Program Track Chairs

Brian J. F. Wong, Beckman Laser Institute and Medical Clinic (United States)

Eva Sevick, The University of Texas Health Science Center at Houston (United States)

Conference Chairs

Brian J. F. Wong, Beckman Laser Institute and Medical Clinic (United States)

Justus F. Ilgner, Uniklinik RWTH Aachen (Germany)

Conference Program Committee

Milind Rajadhyaksha, Memorial Sloan-Kettering Cancer Center (United States)

Henricus J. C. M. Sterenborg, Netherlands Cancer Institute, University Medical Center Amsterdam (Netherlands)

Javier A. Jo, Texas A\&M University (United States)

Amy L. Oldenburg, The University of North Carolina at Chapel Hill (United States)

Session Chairs

1 Optical Technologies for Assessment and Guidance of Middle and Inner Ear Structures and Beyond

Justus F. Ilgner, Uniklinik RWTH Aachen (Germany) 
2 OCT and Related Systems for Monitoring, Modifying and Functional Assessment of Upper Airways I

Brian J. F. Wong, Beckman Laser Institute and Medical Clinic (United States)

3 OCT and Related Systems for Monitoring, Modifying and Functional Assessment of Upper Airways II

Milind Rajadhyaksha, Memorial Sloan-Kettering Cancer Center (United States)

Justus F. Ilgner, Uniklinik RWTH Aachen (Germany)

4 Concepts in Optical Imaging for Early Detection of Head and Neck Malignancies

Brian J. F. Wong, Beckman Laser Institute and Medical Clinic (United States)

Milind Rajadhyaksha, Memorial Sloan-Kettering Cancer Center (United States)

5 Optical and Related Imaging for Detection and Assessment of Invasive Head and Neck Cancer

Brian J. F. Wong, Beckman Laser Institute and Medical Clinic (United States)

Justus F. Ilgner, Uniklinik RWTH Aachen (Germany) 